\title{
NATOV CENTER ODLIČNOSTI ZA GORSKO BOJEVANJE - IZZIVI, PRILOŽNOSTI IN INTERESI
}

\section{NATO MOUNTAIN WARFARE CENTRE OF \\ EXCELLENCE - CHALLENGES, OPPORTUNITIES AND INTERESTS}

Povzetek Na ozemlju Republike Slovenije je marca 2015 kot nova mednarodna organizacija začel delovati Natov center odličnosti za gorsko bojevanje. Institucija z ustanovitvijo, akreditacijo in aktivacijo prinaša vrsto izzivov in priložnosti, kijih lahko zainteresirane strani razvijajo in izkoriščajo. Interesi udeležencev so različni, zato Natov center odličnosti za gorsko bojevanje že v začetni fazi poskuša opredeljevati priložnosti, ki temeljijo na potrebah sodelujočih držav. Za doseganje želene učinkovitosti in kakovosti bo treba upoštevati številne dejavnike, ki opredeljujejo novo institucijo. Obsežen seznam možnosti za razvoj gorskega bojevanja zahteva oblikovanje vsebinskega težišča, na katerega se bo center osredotočal v prihodnje.

Ključne Natov center odličnosti, kolektivna obramba, gorsko bojevanje, doktrina, koncept, besede obrambni sistem.

Abstract NATO Mountain Warfare Centre of Excellence began its operation in March 2015 as a new international organisation in the territory of the Republic of Slovenia. Its establishment, accreditation and finally its activation, bring a number of new challenges and opportunities, which could be developed and exploited by stakeholders and other interested parties. Interests of participants vary; therefore NATO Mountain Warfare Centre of Excellence tries to focus in the very beginning on the opportunities based on the expressed needs and requests. In order to achieve the desired effectiveness and quality, a series of factors defining the new institution will have to be taken into account. A wide range of possible mountain warfare development options calls for the creation of a substantive centre of gravity, which will be the Centre's focus in the future.

Key words NATO Centre of Excellence, collective defence, mountain warfare, doctrine, concept, defence system. 
Uvod Marca 2015 je na ozemlju Republike Slovenije začel delovati Natov center odličnosti za gorsko bojevanje (COGB) kot specializirana, neodvisna mednarodna vojaška organizacija. Vizija centra je razvoj v strokovno vozlišče za razvoj gorskega bojevanja, kar bo članicam ${ }^{1}$ in drugim zainteresiranim subjektom omogočilo vpliv na procese načrtovanja aktivnosti zavezništva, povezane z gorskim svetom. Slovenija se je zavezala, da bo kot nosilna država ustvarila razmere za nemoteno delovanje, vključno s strokovnim kadrom.

Formalni začetki razvoja centra sicer sovpadajo z razvojem Slovenske vojske v devetdesetih letih prejšnjega stoletja, in sicer z ustanovitvijo 32. gorske brigade leta 1992 in Gorske šole leta 1996. Vsebinske podlage segajo dlje v preteklost, saj se je vojaško gorništvo zaradi geografskih značilnosti Slovenije razvijalo že precej pred osamosvojitvijo leta 1991 in se tako gorniška tradicija pravzaprav le nadaljuje. Kot prvo slovensko gorsko enoto literatura navaja preoblikovanje ljubljanskega domobranskega pehotnega polka št. 27 leta 1911, kar zaznamuje tudi začetek slovenskega vojaškega gorništva (Pipan, 2011). Avtorji menimo, da vsak center odličnosti v bistvu združuje obsežen seznam izkušenj, ki takšno institucijo opredeljujejo, zagotavlja pa jih lahko le dolga tradicija.

Republika Slovenija je bila prvič uradno spodbujena k ustanovitvi centra odličnosti leta 2004 ob obisku tedanjega poveljnika Natovega Združenega poveljstva za transformacijo (Blaznik, 2011, str. 37). Zamisel je počasi zorela in se z jedrom gorske šole in gorskega bataljona ter s sodelovanjem različnih ravni znotraj obrambne strukture razvijala do ravni mednarodne organizacije. Leta 2011 je bil ustanovljen večnacionalni center odličnosti, ki je združeval šest držav ${ }^{2}$, po dodatnih štirih letih pa je center izpolnil pogoje za Natovo akreditacijo.

Akreditacija pomeni samo potrditev, da so izpolnjeni ustrezni pogoji za delovanje institucije, aktivacija Vojaškega odbora in Severnoatlantskega sveta pa bo centru omogočila formalno nastopanje $\mathrm{v}$ mednarodnem prostoru. Z ustanovitvijo takšne ustanove Slovenija dokazuje, da želi v zavezništvu aktivno sodelovati tudi pri razvoju obrambnih zmogljivosti, povezanih z bojevanjem $\mathrm{v}$ gorah, in ne le v mednarodnih operacijah in na misijah. Ob tem $\mathrm{v}$ mednarodno okolje posreduje tudi sporočilo o specialističnem težišču razvoja nacionalnih zmogljivosti, kar se bo v prihodnje verjetno odrazilo tudi v nacionalnih strateških dokumentih načrtovanja.

Natov center odličnosti deluje zunaj Natove poveljniške strukture in ni del obrambnih sil države, v kateri ima sedež. To seveda ne pomeni, da Slovenija ne more uporabiti prednosti, ki jih ji center prinaša. S svojimi izdelki lahko vpliva tako na doktrinarne podlage za delovanje zavezništva kot tudi na razvoj nacionalnih zmogljivosti. Tako sooblikuje obrambni sistem zavezništva in hkrati tudi nacionalne obrambne sisteme.

\footnotetext{
Sporazum o soglasju so 25. marca 2015 kot sponzorske države podpisale štiri članice Nata - Hrvaška, Italija, Nemčija in Slovenija, ki je hkrati tudi vodilna država. Ob njihovem soglasju se je pozneje kot partnerska država vključila še Avstrija.

2 Avstrija, Črna gora, Hrvaška, Italija, Madžarska in Slovenija.
} 
Gorsko bojevanje ni nov pojav oziroma termin v vojaških operacijah, saj je gorski svet kot eden izmed dejavnikov od nekdaj vplival na vojaške aktivnosti. Že Sun Tzu je približno petsto let pred našim štetjem gorskemu terenu izkazal posebno spoštovanje z navedbo: "Ne plezaj v višave, da bi se bojeval. Toliko o gorskem bojevanju. $\ll^{3}$ (Giles, 1910, str. 98). Prvi podrobnejši zapisi govorijo o drugi punski vojni, ko je Hanibal leta 218 pred našim štetjem izkoristil gorski svet za premik enot, s katerim je presenetil rimske legije (Liddel Hart, 1967, str. 24-38). V bližnji preteklosti so gorsko bojevanje obravnavali številni vojaški teoretiki, npr. Bourcet (1775), Clausewitz (1812, 1832), Jomini (1862) in drugi, javno dostopni so tudi viri, ki opisujejo sodobnejše vojaške operacije v gorah. Ko pišemo o gorskem bojevanju, o njem razmišljamo v najširšem možnem kontekstu, ki vključuje tudi sodelovanje Z različnimi vladnimi in nevladnimi organizacijami ter vključevanje v operacije kriznega odzivanja. Slednje je na obisku v centru kot pomemben dejavnik izpostavil tudi načelnik generalštaba nemške vojske (Wiecker, 2015).

Nato doslej ni imel razvite specializirane razvojne institucije za gorsko bojevanje, ki bi to področje posebej obravnavala. Natov center odličnosti za gorsko bojevanje je bil ustanovljen z namenom, da ta primanjkljaj zapolni. Da bi zavezništvo ali posamezna država od nove akreditirane in aktivirane institucije dobila rezultate, ki jih potrebuje, mora biti jasno oblikovan interes, ki temelji na poznavanju temeljnega vsebinskega področja, torej vojaških aktivnostih v gorskem svetu in potrebah po njegovi vključenosti v obrambno strategijo.

\section{METODOLOGIJA}

S člankom želimo avtorji predstaviti vlogo Natovega centra odličnosti za gorsko bojevanje $\mathrm{V}$ sistemu nacionalne in kolektivne obrambe. Usmerili se bomo v raziskovalno vprašanje, katera področja lahko pomenijo nove izzive in razvojne priložnosti za novo organizacijo. Ob tem se ne moremo izogniti razpravi o tem, kako nacionalne interese države ustanoviteljice povezovati z interesi sistema kolektivne obrambe.

Glavni metodi proučevanja sta analiza ter interpretacija primarnih in sekundarnih virov ob sočasni uporabi deskriptivne metode, s katero opisujemo normativne podlage. Ker avtorji izhajamo neposredno iz obravnavane organizacije, izkoriščamo tudi možnosti opazovanja z udeležbo. Ob tem izpostavljamo dejstvo, da smo za pripravo članka uporabljali izključno javno dostopne podatke in informacije brez stopnje zaupnosti. To sicer predstavlja nekaj omejitev, ki pa za obravnavano področje nimajo večjega pomena.

\footnotetext{
Obstajajo manjše razlike v prevodih izvirnega besedila. V vseh pa je vsebina usmerjena v tveganost bojevanja $v$ višinah. Če možnosti omogočajo, dvignjen gorski svet izkoristimo za lastne obrambne položaje in nadzor območja. Bojnemu stiku z nasprotnikom, ki že nadzoruje takšne položaje, pa naj bi se v takšnem okolju skušali izogibati.
} 
Komparativna metoda je sestavni del razprave o vlogi COGB v sistemu kolektivne in sistemu nacionalne obrambe.

Sinteza spoznanj se odraža v sklepnih poglavjih, v katerih avtorji predlagamo usmeritve in izhodišča za nadaljnje delo ter konkretne rešitve, ki lahko določajo razvoj organizacije v prihodnje.

\section{OPREDELITEV POJMOV}

Razprava o centru odličnosti kot gradniku obrambnega sistema zahteva jasno opredelitev pojmovnega aparata, ki omogoča ustrezno razumevanje obravnavanih vsebin. $\mathrm{V}$ ta namen moramo razčleniti obrambni sistem $\mathrm{v}$ nacionalnem in mednarodnem pomenu ter okvirno pojasniti institut centra odličnosti.

Obrambni sistem je celota vojaških in nevojaških elementov (enot, ustanov, zmogljivosti, postopkov in norm) $\mathrm{v}$ nacionalnovarnostni strukturi, namenjenih opravljanju obrambno-zaščitnih funkcij družbe (Grizold, 1999, str. 40). Njegova vsebina je odvisna od različnih dejavnikov, kot so mednarodno okolje, zgodovinske, geografske, demografske, politične, razvojne in druge okoliščine (prav tam, str. 11). Za našo razpravo pa moramo razumevanje obrambnega sistema razširiti tudi v mednarodno okolje oziroma v doseganje mednarodne varnosti. Ta ni zgolj seštevek nacionalnih elementov, temveč gre za stalni mednarodni okvir splošno sprejemljivih vrednot (Grizold, 1992, str. 66), ki se poleg univerzalnih, sprejetih v OZN, kaže tudi v sistemu zavezništva.

Natov COGB se ponuja kot šolski primer organizacij, ki zagotavljajo proučevanje in razvoj tako imenovanih nišnih zmogljivosti (Stanhope, 2005, str. 1), saj so v svojem delovanju praviloma usmerjene na ozka in specializirana področja in se nanašajo na ugotovljene pomanjkljivosti v delovanju Natovih enot in poveljstev. Delovanje centrov odličnosti na podlagi načela inovativnega razmišljanja, kot ga izpostavlja Stanhope, pomeni velik intelektualni potencial Nata. Centri odličnosti so namenjeni preoblikovanju zavezniških sil, povečanju in izboljšanju posebnih zmogljivosti ter predvsem učinkovitejši izrabi že oblikovanih zmogljivosti članic zveze ter partnerskih držav. Centri odličnosti, ki so pomembna vez med operativnimi zmogljivostmi Nata in okoljem, uresničujejo svoje poslanstvo v podporo tem ciljem (Blaznik, 2011, str. 27).

\section{CENTER ODLIČNOSTI V SISTEMU KOLEKTIVNE OBRAMBE}

Ko govorimo o povezavi centra odličnosti za gorsko bojevanje in kolektivne obrambe, imamo v mislih možnosti, ki jih center lahko ponudi širši interesni skupnosti, in vključuje države zavezništva, vključno s sedanjimi partnerskimi povezavami. Gre za možnosti aktivnega sodelovanja pri razvoju novih rešitev na področjih, povezanih z vojaškim angažiranjem v gorskem svetu. Želeni cilj je doseganje višje stopnje 
standardizacije 4 in s tem odzivnosti ter učinkovitosti specializiranih zmogljivosti za gorsko bojevanje. Nato se kot sistem kolektivne obrambe in kolektivne varnosti ${ }^{5}$ ves čas preoblikuje skladno z varnostnimi razmerami in položajem v mednarodnem okolju. Ta proces upošteva tehnološke in druge razvojne trende in poskuša uveljaviti prilagoditve $\mathrm{v}$ najkrajšem mogočem času. Kot sta zapisala Charles in Clifford Kupchan (1995), je to pogojeno $\mathrm{z}$ visokim soglasjem interesov in vrednot vseh udeležencev. Natov COGB lahko interese, povezane z njegovimi pristojnostmi in zmožnostmi, spremlja prek izraženih potreb na različnih ravneh, jih analizira in pripravlja predloge posameznih rešitev. Tako je omogočeno neposredno vplivanje na delovanje zavezništva, ki bo ob potrjenih končnih izdelkih lahko sledilo njihovim določilom. Pripravo končnih izdelkov bodo poleg izhodiščnih potreb opredeljevale tudi zahteve, izhajajoče iz političnega konteksta zavezništva. Kot se je izrazil Natov poveljnik za transformacijo (Palomeros, 2014), lahko center s svojo specialistično naravnanostjo znatno prispeva $\mathrm{k}$ izboljšanju skupnih zmogljivosti pri spopadanju $\mathrm{z}$ varnostnimi spremembami v mednarodnem okolju. Glavne prednostne naloge vidi na področjih doktrinarnega razvoja, prispevka $\mathrm{k}$ skupnim vajam in razvoju ter pri izvedbi programov usposabljanja.

Vizija COGB je postati osrednja strokovna ustanova za pridobivanje znanja oziroma spoznanj o gorskem bojevanju v Natu. Namenjen je zagotavljanju odličnosti in strokovnosti na področjih usposabljanja in urjenja posameznikov in enot, pri podpori razvoju doktrin, učenju iz izkušenj, raziskavam, oblikovanju standardov ter pri procesu preoblikovanja enot za gorsko bojevanje (Nato MW COE Concept, 2014). Pot do uresničitve ciljev ne bo niti hitra niti preprosta. Že proces akreditacije, ki sledi formalni ustanovitvi s podpisom sporazuma o soglasju držav članic (Nato MW COE Memorandum of Understanding, 2014), opredeljuje številna merila, ki jih mora center izpolnjevati za uspešno delo. Temelj pozitivne ocene sta akreditacijski vprašalnik in pozitivno poročilo predstavnikov Natovega poveljstva za transformacijo. Institucija je formalno aktivirana s potrditvijo akreditacije na Vojaškem odboru Nata in Severnoatlantskem svetu. Po končanih formalnih postopkih se lahko vse aktivnosti centra osredotočijo na vsebinsko delo. Glavni namen centra odličnosti je izboljševanje Natovih zmogljivosti, pri čemer vsebina vedno pomeni dodano vrednost - torej je vnaprej jasno, kdo produkt potrebuje, kakšni so namen in cilji ter da je vnaprej izločeno vsakršno podvajanje aktivnosti v zavezništvu.

Mednarodna interesna skupnost, ki je za delovanje centra odličnosti nujna, za to vsebinsko področje že obstaja, sicer bi bila njegova ustanovitev nemogoča. Za

\footnotetext{
4 Razvoj in uvajanje novih konceptov, doktrin, postopkov in modelov, s katerimi se dosegajo in vzdržujejo združljivost, zamenljivost in poenotenje. Te so nujne za zagotavljanje ustrezne ravni interoperabilnosti oz. za optimizacijo uporabe virov na področjih operacij, materialno-tehničnih sredstev in upravljanja aktivnosti (AAP42, 2011).

5 Ob zagotovljenem širokem mednarodnem konsenzu, izraženem z mandatom OZN. Bistvo kolektivne varnosti sta kolektivno varovanje miru in skupen odziv na kršitelje, zahtevata pa visoko soglasje interesov in vrednot vseh udeležencev. Kolektivna varnost se je po 2. sv. vojni modificirala z Ustanovno listino OZN, najpomembnejši del za vzpostavitev pa je bila določitev petih stalnih članic Varnostnega sveta, ki s soglasjem volje za uspeh prisilnih akcij zagotavljajo uspeh sistema. Varnostni svet ima predvsem odgovornost, da ohranja mednarodno varnost in mir (Türk, 2007, str. 503-511; Conforti, 2005, str. 386-387).
} 
povezovanje $\mathrm{v}$ smeri poenotenega nastopanja $\mathrm{v}$ mednarodnem okolju pa bo treba vložiti veliko energije in med seboj povezati več nacionalnih vojaških enot, združenj, organizacij in ustanov, ki v bistvu sicer delujejo po enakem vrednotnem sistemu, so pa močno oprte na lastno tradicijo. Razlike je mogoče zmanjšati z intenzivno organizacijo različnih aktivnosti, ki omogočajo skupno delo na področju gorskega bojevanja.

COGB deluje skladno z veljavno Natovo politiko, doktrinami in standardi. Na področju obrambnih aktivnosti $\mathrm{v}$ gorskem svetu se od institucije upravičeno pričakujejo razvoj novih konceptov, predlogi za izboljšave veljavnih postopkov, standardov in doktrin ter aktivno sodelovanje pri uvajanju novosti $\mathrm{v}$ uporabo ob konkretnih aktivnostih zavezništva. Vsaka novost mora biti čim prej po potrditvi dostopna uporabnikom pri opravljanju nalog ${ }^{6}$ - torej v mednarodnih operacijah in na misijah, v programih izobraževanja in usposabljanja, v vseh fazah, od načrtovanja do končnih evalvacij. Izdelki morajo vključevati najnovejša spoznanja in izkušnje, ki odražajo resnične potrebe uporabnikov, sicer so lahko zaznani le kot dodatna administrativno opredeljena naloga, ki je na terenu neuporabna, posledica pa so nespremenjeni procesi, na katere želimo vplivati (Zupančič, 2015).

Skladno s svojim poslanstvom COGB tesno sodeluje z Natovim poveljstvom za transformacijo in promovira njegove transformacijske cilje. $\mathrm{Na}$ področju razvoja sedanjih in prihodnjih zmogljivosti lahko zazna primanjkljaje ter jih s predlogi rešitev odpravlja oziroma prispeva $\mathrm{k}$ zmanjševanju posledic. $\mathrm{K}$ povezljivosti pri preoblikovanju zavezništva lahko center prispeva z zbiranjem informacij o trenutnih nacionalnih zmogljivostih in možnostih za njihovo uporabo v kontekstu kolektivne obrambe. Medsebojna povezanost nacionalnih zmogljivosti za delovanje v gorskem svetu bo omogočila jasen pregled nad možnostmi in izpostavila nove potrebe po standardizaciji za učinkovito sodelovanje. Na področju razvoja partnerskih povezav bo COGB sledil politiki odprtih vrat. V sedanjih in prihodnjih novih povezavah bo velik del dogodkov odprt za zainteresirano strokovno javnost tudi iz držav, ki niso članice zavezništva, jih pa z njim povezujejo skupne vrednote in interesi?

Med vsebinami gorskega bojevanja, ki bi jim lahko v prihodnje namenili več pozornosti, lahko izpostavimo (Zupančič, 2015):

- področno terminologijo,

- poveljevanje in kontrolo,

- opremo in oborožitev,

- programe izobraževanja in usposabljanja,

- taktične in tehnične postopke.

\footnotetext{
${ }^{6}$ Na to je ob obisku v centru opozoril tudi poveljnik kopenskih sil ZDA za Evropo, general Hodges (2015), ki zaznava, da je čas od izražene potrebe do formalne potrditve in uporabe končnih izdelkov na terenu predolg.

7 Avtorji imamo s tem v mislih predvsem države, ki so vključene v Partnerstvo za mir, Mediteranski dialog, Istanbulsko pobudo ter program Globalnega partnerstva.
} 
Marsikaj izmed naštetega je že pripravljeno in uvedeno na ravni nacionalnih zmogljivosti držav ${ }^{8}$, za skupno usklajeno delovanje v zavezništvu pa bo vsebine treba prepoznati, preveriti njihovo veljavnost v širšem kontekstu, jih medsebojno uskladiti, predlagati konkreten izdelek in spremljati proces do končne potrditve. Tudi v fazi uveljavljanja novosti lahko COGB opravi svojo nalogo z obveščanjem in uvajanjem podpore z dodatnimi informacijami, če bo treba.

Specializirane doktrine za gorsko bojevanje kot samostojne publikacije v Natu trenutno še ni. Izhodiščna doktrinarna podlaga za razvoj gorskega bojevanja ${ }^{9}$ opredeljuje operacije v gorah kot del kopenskih operacij. Gre za splošen pregled in opredelitev nekaterih temeljnih parametrov, ki so lahko izhodišče za nadaljnji razvoj. Natov COGB bi lahko predlagal izboljšave Natove doktrine na področjih, ki so povezana z gorskim bojevanjem oziroma vključujejo njegove konkretne vidike. Trenutno so te vsebine razpršene predvsem v hierarhiji zavezniških publikacij kopenske vojske ${ }^{10}$, usklajenost pa mora biti zagotovljena po celotni strukturi, vključno z združenimi doktrinami ${ }^{11}$. Tak izdelek zahteva svoj čas in naj na tem mestu zapišemo, da je vsako doktrino treba zgraditi postopoma, ne zgolj napisati. Za pripravo doktrinarne publikacije morajo biti na voljo tradicija oziroma uveljavljen sistem vrednot, ustaljena praksa in preverjene izkušnje ${ }^{12}$, obseg standardov za postopke in opremo ter na ustrezni ravni izražena potreba po združitvi gradiva $\mathrm{v}$ enoten doktrinarni izdelek.

Temelj za razvoj konceptov gorskega bojevanja so trenutni trendi, povezani $\mathrm{s}$ konceptom pametne obrambe in pobudo povezanih sil. COGB bo skladno z možnostmi in potrebami lahko sodeloval tudi pri razvoju specialistične opreme, saj je ta pomemben element zagotavljanja učinkovitosti in povezljivosti posameznikov in enot. Trenutno je v ospredju projekt razvoja zložljivih turnih smuči, pri katerem center sodeluje s podjetjem Elan, in že zbuja zanimanje pri najvišjih predstavnikih zavezništva (Palomeros, 2014; Hodges, Stoltenberg, 2015).

V sodelovanju z Natovim poveljstvom za transformacijo bo center v prihodnje aktivno spremljal pripravo strateškega načrta usposabljanja in analize zahtev, v končni fazi pa sodeloval pri oblikovanju analize končnih potreb za usposabljanje

\footnotetext{
8 V Sloveniji $k$ vojaškemu gorništvu in taktiki bojevanja v gorah pomembno prispeva Miha Kuhar (2004, 2008).

9 Ta pojem razumemo kot vsebine, ki so del drugih, področnih, doktrinarnih publikacij zavezništva in se nanašajo na vsebine gorskega bojevanja. Razumljivo je, da je večina vsebin uvrščena v publikacije kopenske vojske, čeprav so v gorsko bojevanje lahko vključene tudi druge zvrsti.

${ }^{10}$ ALPA - Allied Land Publications Architecture.

${ }^{11}$ AJDA - Allied Joint Doctrine Architecture.

${ }_{12}$ Zaznane lekcije, ki so pridobljene iz različnih virov (mednarodne operacije, vaje in različne druge oblike usposabljanj), morajo biti dodatno preverjene in potrjene v pristojnih institucijah, da so kot naučene lekcije lahko uporabne za širšo uporabo in postanejo del doktrinarnih vsebin (The NATO Lessons Learned Handbook, 2011).
} 
na ravni zavezništva ${ }^{13}$. Na podlagi tega bo center lahko vzpostavil pregled nad že delujočimi programi, pozneje pa bo na podlagi potreb lahko pristopil k združevanju, usklajevanju, standardizaciji sedanjih ali razvoju novih vsebinskih sklopov. Specialistična izobraževanje in usposabljanje sta že v temelju draga aktivnost, ki zahtevata veliko virov od posamezne države, zato se tudi za gorsko bojevanje center odličnosti kaže kot primerna alternativa za prenos specializiranih vsebin (Guiney, 2015). COGB bo analiziral zaznane pomanjkljivosti s področja gorskega bojevanja ter zagotavljal, da bodo predlogi za izboljšave skladni z veljavnimi doktrinami in standardi oziroma bodo prispevali k njihovi nadgradnji. Najpomembnejše so zagotovo izkušnje, pridobljene v različnih vojaških operacijah, saj morajo biti zmogljivosti zasnovane na podlagi konkretne naloge. Povezovanje z vodilnimi ustanovami s tega področja ${ }^{14}$ je seveda samoumevno.

Možnosti za sodelovanje COGB pri kolektivni varnosti in obrambi je veliko. Določanje prednostnih nalog bo odvisno od zahtev in potreb zavezništva ter drugih dejavnikov, povezanih predvsem s kadrovskimi, materialnimi in finančnimi viri.

\section{UVELJAVLJANJE NACIONALNEGA INTERESA V CENTRU ODLIČNOSTI}

Preden se lotimo razprave o uveljavljanju nacionalnih interesov v centru odličnosti, je dobro vsaj omeniti nekaj dilem, ki se ob tem pojavljajo. Glavna težava je namreč v tem, da je vsaka razprava o nacionalnih interesih čustveno obarvana (Svetličič, 2002, str. 524), jasna definicija pojma pa je skoraj nemogoča, saj gre običajno za prepletanje interesov različnih skupin ali celo vplivnih posameznikov. Najsplošnejšo definicijo podaja slovar svetovne politike (Evans in Newman, 1992, str. 207), ki pravi, da se nacionalni interes uporablja kot sredstvo za identifikacijo ciljev ali namenov zunanje politike in kot vsesplošen koncept političnega diskurza, še posebej za opravičevanje posebnih političnih preferenc.

Zadnji predlog Deklaracije o zunanji politiki Republike Slovenije ${ }^{15}$ nacionalni interes usmerja $\mathrm{v}$ ohranjanje suverenosti, varnost državljank in državljanov ter varovanje in uveljavljanje ustavnih vrednot. Deklaracija izpostavlja pomen strateških dokumentov, ki opredeljujejo nacionalno varnost, ta pa je širše, tudi z vidika mednarodne varnosti, označena kot primarni cilj slovenske zunanje politike. Med drugim je v deklaraciji zapisana tudi potreba po krepitvi vidnosti in vloge Republike

\footnotetext{
${ }_{13}$ Načrtovalni cikel poteka znotraj posameznih disciplin, opredeljenih v Natovi politiki izobraževanja in usposabljanja (www.nato.act.int). Gorsko bojevanje trenutno ni opredeljeno kot samostojna disciplina, zato se namerava Natov COGB vključevati na področju kopenskih operacij, ki ga usklajuje Poveljstvo za kopenske operacije (LANDCOM, Izmir, Turčija).

${ }^{14}$ JALLC - Joint Analysis and Lessons Learned Centre, Lizbona, Španija; JWC - Joint Warfare Centre, Stavanger, Norveška; JFTC - Joint Force Training Centre, Bydgoszcz, Poljska, sorodni centri odličnosti in druge institucije.

${ }_{15}$ Vlada RS je na 37. redni seji 21. maja 2015 sprejela besedilo deklaracije in jo poslala v nadaljnjo obravnavo Državnemu zboru. Temu bosta v prihodnje sledila oblikovanje krovnega strateškega dokumenta o zunanji politiki RS in priprava izvedbenih aktov.
} 
Slovenije v Natu kot temeljnem okviru nacionalne in evropske varnosti. Novi Natov center pri tem pomeni pomemben prispevek, saj so se v slovenskem prostoru z njim pojavile nove možnosti sodelovanja z zavezništvom. Pomeni namreč nadgradnjo sicer aktivnega varnostnega in obrambnega sodelovanja $v$ vojaških operacijah in na misijah ter $\mathrm{v}$ različnih delovnih telesih Nata, ki se lahko v prihodnje odrazi v povečanem vplivu na politiko, strategijo in koncepte zavezništva. Ob tem pa ne smemo pozabiti, da gre za mednarodno institucijo, v kateri se bodo prepletali interesi vseh sodelujočih držav. Bogata gorniška tradicija alpskih držav, močno razvite vojaške gorske enote, predvsem ustanovnih članic Nemčije, Italije in Avstrije, se bodo $\mathrm{v}$ izdelkih in nastopanju institucije odražale tako strokovno kot politično ${ }^{16}$. Slovenija mora poleg temeljnih razmer za delo centra prispevati tudi korekten vsebinski del, za katerega mora strokovno podlago zagotavljati v svojih gorskih enotah, ki so v sestavi Slovenske vojske. Mednarodne izkušnje, predvsem v obdobju po letu 2004, ko je naša država začela sprejemati normative in standarde Nata, lahko zagotovijo učinkovito vključevanje v glavna delovna telesa in ustrezno sodelovanje z organizacijami in agencijami, ki sooblikujejo Natovo politiko (slika 1).

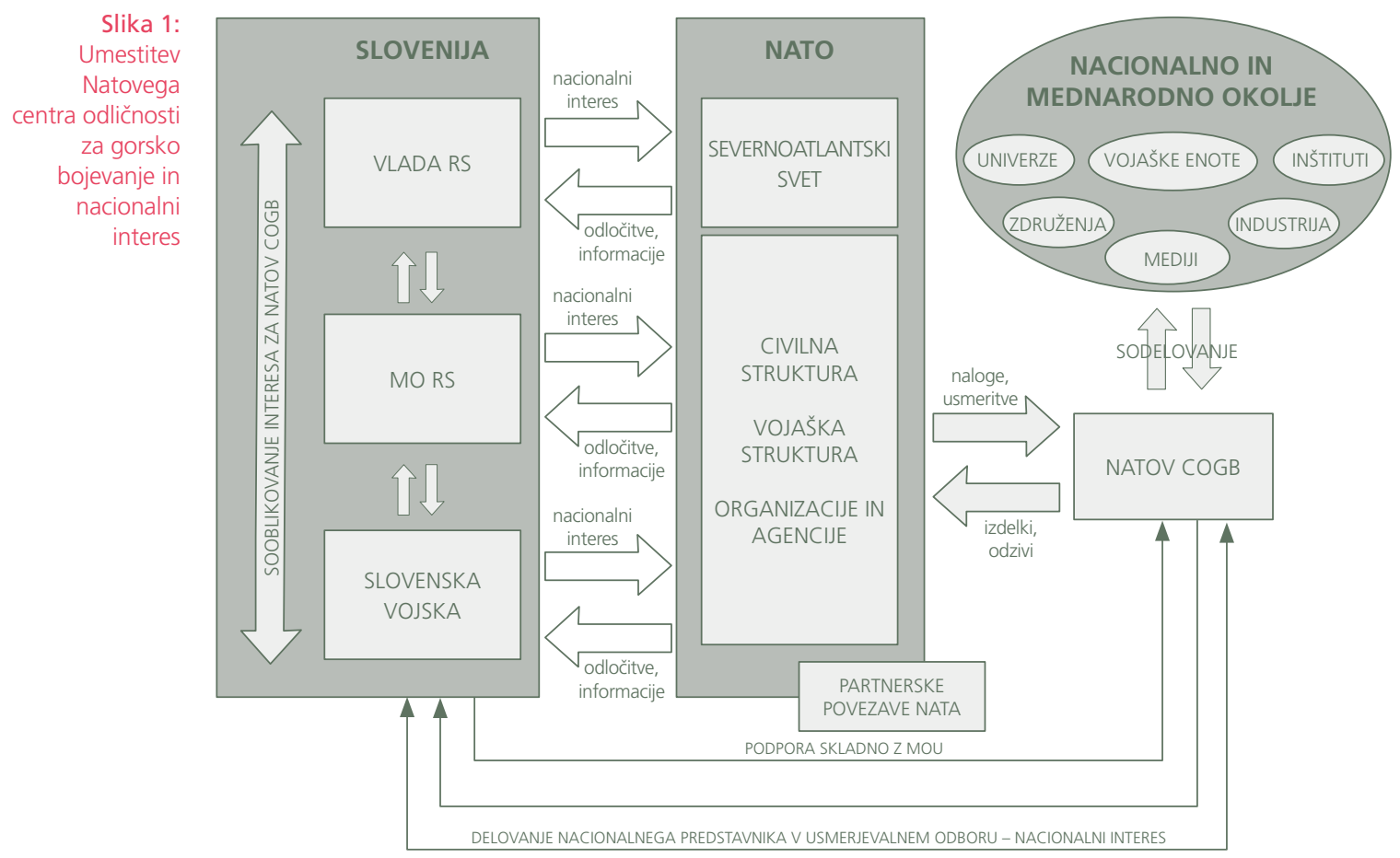

${ }^{16}$ Vsak končni izdelek (npr. standard), ki bo prispeval k vsebinam zavezništva, mora biti soglasno potrjen na Vojaškem odboru Nata. Torej je treba zagotoviti soglasje vseh držav, ne zgolj sodelujočih v Natovem COGB. V prihodnosti center resno računa na dodatno vključevanje držav s svojimi strokovnjaki, ki bodo lahko prispevali k izmenjavi mnenj ter poenotenju vsebin. 
Slovenija je med državami Evropske unije uvrščena na tretje mesto po deležu občin v gorskem svetu. Po metodologiji raziskave Sveta Evrope ${ }^{17}$ Slovenija dosega kar 78 odstotkov, večji delež gorskih občin imata le Norveška in Švica (Nordregio, 2004, str. 24). Poleg tega več kot 64 odstotkov slovenskega prebivalstva živi na gorskih območjih (Nordregio, 2004, str. 28). Skladno z ožjo, zgolj reliefno usmerjeno klasifikacijo je delež terena nad 1000 metri nadmorske višine v Sloveniji slabih 13 odstotkov, skupaj s hribovitim svetom pa dodatnih 35 odstotkov (Geografski atlas Slovenije, 2010, str. 55). Ti podatki kažejo, da je z vidika nacionalne obrambe v izobraževanje in usposabljanje slovenskih obrambnih zmogljivosti tudi v prihodnje nujno uvrščati vsebine, ki omogočajo učinkovito bojno delovanje v gorskem svetu. $\mathrm{V}$ ta namen so pristojni organi Generalštaba Slovenske vojske že pripravili usmeritve, ki bodo to omogočile. Ob tem pa se moramo zavedati, da tečaji predstavljajo zgolj začetek oziroma vezni element med stalnim usposabljanjem specialistov za gorsko bojevanje. Kot piše Kuhar (2008, 2014), sta za vzdrževanje in nadaljnji razvoj gorskih specialistov na vseh ravneh odločanja nujna nenehno obiskovanje gora in delo v tem okolju. Vremenski vplivi, višine in geografska območja širijo obseg izkušenj, s čimer se lahko posameznikovo dojemanje gorskega okolja spremeni iz grožnje v priložnost. Tako bo enota lahko izkoristila vse možnosti, ki jih to okolje ponuja za uspešno izvedbo naloge. Interes Slovenske vojske je torej iskanje novih priložnosti za pridobivanje izkušenj, tako v domačih kot tujih gorstvih, ter njihova nadaljnja uvedba na vse ravni delovanja.

Poleg splošnih geografskih dejavnikov, ki jih ne smemo zanemariti, imajo na potek vojaških aktivnosti največji neposreden vpliv fizični geografski dejavniki. Ti so namreč podlaga za opredelitev načina poveljevanja in kontrole, vodenja ognja, zaščite in maskiranja, smeri delovanja ter načina logistične zagotovitve (Bratun, 2005, str. 67). Slovenska Vojaška doktrina gorskega sveta sicer ne izpostavlja posebej, poudarja pa pomembnost upoštevanja terenskih in vremenskih okoliščin, ki lahko vplivajo na potek vojaških operacij in operacij, povezanih z zaščito in reševanjem (Furlan, 2006). V slovenskem okolju sicer lahko samostojno ustvarimo razmere za izvajanje vojaških vaj, ki vključujejo gorsko bojevanje, vendar se spopadamo s precejšnjimi omejitvami $^{18}$. V domovini je Slovenska vojska omejena predvsem z možnostmi za izvedbo bojnega streljanja v gorskem okolju, druge aktivnosti pa lahko izvajamo ali na terenu ali ob kombiniranju z računalniško podprtimi scenariji. Možnosti za udeležbo na večjih vajah zavezništva gotovo predstavljajo velik potencial pri iskanju novih priložnosti, tako centra kot Slovenske vojske. Delovanje gorskih enot je lahko osrednja vsebina taktične situacije, lahko pa gre le za manjši del, ki vključi specialistične enote. Kot pravi Škerbinc (2014), je verjetno »/.../ najpomembnejše to, da se bo delo 132. gorskega polka, Gorske šole SV in Natovega centra odličnosti za gorsko bojevanje medsebojno dopolnjevalo, usklajevalo in vzajemno podpiralo.

\footnotetext{
${ }^{17}$ Mountain Areas in Europe: Analysis of mountain areas in EU member states, acceding and other European Countries, Nordregio 2004. Uporabljen je bil prilagojeni globalni model UNEP - WCMC (United Nations Environment Programme - World Conservation Monitoring Centre), ki upošteva kombinacijo nadmorskih in relativnih višin, naklone terena in možnosti rabe zemljišča.

${ }_{18}$ Predvsem omejitve, ki so povezane z zaščitenim območjem Triglavskega narodnega parka, in splošne zakonske omejitve, ki opredeljujejo zaščito naravnega okolja.
} 
Vsaka organizacija bo pri tem nekaj prihranila, po drugi strani pa bodo sinergijski učinki prinesli koristi tako Slovenski vojski kot tudi Zavezništvu«. Temu lahko dodamo tudi usklajenost preostalih nacionalnih zmogljivosti, ki lahko zagotovijo učinkovito prisotnost in delovanje ustreznih zvrsti $^{19}$, rodov in služb v gorskem svetu.

Natov COGB bo s sledenjem svoji viziji zbiral, analiziral in objavljal veliko množino različnih informacij, ki bodo izhajale iz mednarodnih operacij, vojaških vaj in drugih obrambnih aktivnosti v različnih gorskih okoljih sveta. Povezanost s specializiranimi institucijami znotraj Nata in zunaj njega bo omogočila pretok zaznanih in naučenih lekcij, zaznavanje primanjkljajev in potreb na različnih področjih gorskega bojevanja ter oblikovanje rešitev, za katere bo zanimanje. Kot ugotavlja že Šteiner (2008), bo " /.../ center prek transformacijskega internetnega omrežja povezan v izmenjavo znanj in izkušenj. Analiziranje izkušenj ter čimprejšnji prenos v prakso pa je izredno pomembno transformacijsko orodje pri spreminjanju vojsk in njihovem prilagajanju sodobnim razmeram«. Za Slovenijo odprtje centra pomeni dodatno priložnost dostopa do obdelanih podatkov in informacij, ki bodo lahko pripomogle k izgradnji lastnih zmogljivosti.

Pripravo konkretnih izdelkov lahko posamezna država uvrsti v redni program dela centra. To lahko doseže (glej sliko 1):

- prek nacionalnih predstavnikov v zavezništvu, ki prek Natovega Poveljstva za transformacijo zahtevek posredujejo Natovemu COGB;

- prek nacionalnega predstavnika v Usmerjevalnem odboru Natovega COGB.

Končno odločitev o uvrstitvi naloge v letni načrt dela sprejme Usmerjevalni odbor, ki oceni možnosti za kakovostno izvedbo. Seveda pa je ob vsaki takšni aktivnosti nujna predhodna analiza, s katero predlagatelj opredeli namen in cilje ter preveri morebitne veljavne rešitve in zanimanje med drugimi državami.

Centri odličnosti v splošnem lahko vplivajo na politiko, doktrine in standarde Nata. V tem delu mora imeti država kot celota izoblikovane cilje, ki jih želi doseči. Moramo pa opozoriti, da temeljno poslanstvo teh institucij ni zadovoljevanje nacionalnih interesov, temveč predvsem kolektivnih. Najlažje se nacionalni cilj uresniči, ko ga državi uspe vključiti v seznam kolektivnih ciljev. Ključno vlogo za doseganje želenega ima povezanost nacionalne zunanje politike, obrambne diplomacije in strokovnega okolja v strukturi Slovenske vojske, ki se lahko odraža s poenotenim nastopanjem slovenskih predstavnikov na različnih ravneh zavezništva.

V obdobju od prvih zamisli do ustanovitve Natovega centra odličnosti za gorsko bojevanje je bilo v slovenskem strokovnem prostoru veliko razprav o tem, ali je takšen projekt mogoče uresničiti, ali je sploh potreben in kaj bi Slovenija z njim pridobila. Soočali smo se z številnimi vprašanji, trenutno pa se center ob spodbudi mednarodne

\footnotetext{
${ }^{19}$ V slovenskem prostoru imamo v mislih predvsem kopensko vojsko in letalstvo. Splošno gledano pa se podpora gorskemu bojevanju lahko izvaja z vseh platform, tudi mornariških.
} 
skupnosti in podpori slovenske obrambne diplomacije ter z aktivnim sodelovanjem pristojnih organov Slovenske vojske vključuje v mednarodne strukture.

Neodvisnost centra je temeljno načelo, ki omogoča osredotočanje na specialistične vsebine institucije, v našem primeru na gorsko bojevanje. V tem primeru seveda ne moremo govoriti o neodvisnosti v najširšem pomenu, pač pa zgolj o izločitvi institucije iz kakršne koli linije poveljevanja in kontrole. Kljub temu Natovo poveljstvo za transformacijo nenehno usklajuje delo vseh centrov odličnosti in občasno ocenjuje izpolnjevanje veljavnih meril, ki so pogoj za delovanje Natovih teles. Organizacija odpira veliko novih možnosti za delo, ki so v nacionalnem okolju zaradi različnih vzrokov običajno težje dosegljive. Udeleženost $\mathrm{v}$ konkretnem projektu namreč zahteva sledenje splošni metodologiji raziskovanja, ob tem pa hkrati upoštevanje različnih omejitev, ki so sestavni del zavezništva in nacionalnih obrambnih sistemov. Vsak nov projekt je lahko izziv in nova priložnost, hkrati pa s seboj prinaša tudi odgovornost posameznika in kolektiva. Za doseganje dolgoročnega uspeha bo treba pazljivo uravnavati razmerje med usmerjenostjo organizacije $\mathrm{v}$ doseganje ciljev in oblikovanje organizacije kot skupnosti interesov ${ }^{20}$. Center odličnosti lahko učinkovito deluje le kot skupnost interesov, saj gre v bistvu za timsko delo, visoko stopnjo sploščenosti organizacije in nenehno potrebo po prilagajanju. Tradicionalna hierarhija v smislu čakanja na ukaze in njihovo izpolnjevanje ne more zagotoviti temeljne, razvojno usmerjene dejavnosti institucije.

Priporočila V obdobju po aktivaciji bo treba aktivnosti usmeriti v povečanje prepoznavnosti in sklepi in oblikovanje verodostojnosti. Prvo bo lažje, saj gre predvsem za prisotnost na čim več dogodkih, na katerih ima center možnost predstavljati svoje delo in načrte za prihodnost. Doseganje verodostojnosti pa je dolgotrajnejši proces, saj bo treba pripraviti konkretne predloge, ki bodo prepričljivi za širšo mednarodno strokovno javnost.

Past, ki jo avtorji zaznavamo, je izbira osredotočenja na konkretne vsebine. Gradiva in možnosti je veliko, interesi sodelujočih različni, kadrovski, finančni in materialni viri pa so omejeni. Zato je že v začetnem obdobju treba raziskati možnosti, jasno določiti, kaj ima prednost, se vključiti v perspektivne projekte in v njih z vso energijo sodelovati do končnih rezultatov. Naloge, v katerih zahteva po njihovem razvoju ne bo jasno opredeljena, ne smejo obremenjevati letnega programa dela in proračuna centra, saj razpršenost aktivnosti povečuje možnosti za pojav delovnih zastojev, nedokončanih projektov in posledično povečanja nemotiviranosti sodelujočih ter zmanjšanja verodostojnosti centra.

Slovenija je z ustanovitvijo centra v mednarodno skupnost poslala jasno sporočilo o svojih prednostnih nalogah, ki naj bi bile usmerjene v razvoj zmogljivosti za gorsko bojevanje. Temu bi bilo seveda treba prilagoditi strateške načrtovalne dokumente in ob tem preveriti možnosti sodelovanja z drugimi projekti oziroma s projekti, ki se

${ }^{20}$ Primerjavo konceptov organizacije kot instrumenta in organizacije kot skupnosti interesov natančno analizira Tavčar (2009). 
uvajajo na novo. Velik del vsebin je uporaben tudi na področju zaščite in reševanja, katerih pomen in vloga se z razvojem varnostnih razmer nenehno povečujeta. Poleg temeljne dejavnosti bojevanja $\mathrm{v}$ gorskem svetu so tudi naravne in druge nesreče $\mathrm{v}$ težko dostopnih okoljih področja, na katerih center lahko prispeva konkretno vsebino.

Ob že omenjenih področjih, na katerih lahko center konstruktivno sodeluje, bo moral kot nova organizacija čim prej:

- prilagoditi način razmišljanja vseh zaposlenih z nacionalno usmerjenega na globalnega;

- uveljaviti aktiven pristop, priložnosti si mora poiskati samostojno, ne zgolj pasivno čakati;

- sprejeti veljavna spoznanja in jih umestiti v aktualne potrebe.

Tudi nacionalno okolje, ki je s svojo podporno funkcijo zelo pomembno za delovanje centra, mora biti natančno seznanjeno z njegovimi posebnostmi, saj lahko sicer pride do nepotrebnih zastojev in podvajanj delovnih procesov.

Zaposleni v centru smo med procesi ustanavljanja, akreditiranja in aktiviranja pridobili vpogled $\mathrm{v}$ širino problematike in možnosti prihodnjega dela. Zelo dobro se zavedamo, da smo na začetku poti, ki ponuja veliko izzivov, priložnosti in smeri. Nekatere so ocenjene z visoko oceno težavnosti, če uporabimo nekaj gorniškega izrazoslovja. Z znanjem ter preglednim načinom dela bomo v mednarodni zasedbi preplezali tudi te.

1. Blaznik, B., 2011. Večnacionalni center odličnosti za gorsko bojevanje. Zaključna naloga. Maribor: Poveljniško-štabna šola.

2. Bourcet, P. J., 1775. Principes de la Guerre de Montagnes. Paris: Imprimerie Nationale. http://www.gallica.bnf.fr, 22. 7. 2015.

3. Bratun, Z., 2005. Vojaška geografija I. Ljubljana: Fakulteta za družbene vede.

4. Brožič, L., 2014. Začetek delovanja Natovega centra odličnosti za gorsko bojevanje v Sloveniji vse bližje. VRevija Obramba, januar 2015, str. 4-6. Ljubljana: Defensor.

5. Clausewitz, C., 1812. The Principles of War. http://www.clausewitz.com, 22. 7. 2015.

6. Clausewitz, C., 1832. Vom Kriege. Berlin: Dümmlers Verlag. http://www.clausewitz.com, 22. 7. 2015.

7. Conforti, B., 2005. Mednarodno pravo. Ljubljana: Fakulteta za družbene vede.

8. Dupuy, T. N., 1993. International Military and Defence Encyclopedia. Vol. II (C-F). Washington: Brassey's.

9. Evans, G. in Newman, J., 1992. The Dictionary of World Politics. New York, London, Toronto, Sydney, Tokyo, Singapore: Harvaster Wheatsheaf.

10. Furlan, B., 2006. Vojaška doktrina. Ljubljana: Poveljstvo za doktrino, razvoj, izobraževanje in usposabljanje.

11. Geografski atlas Slovenije, 2010. Ljubljana: DZS.

12. Giles, L., 1910. The Art of War, by Sun Tzu. http://www.manybooks.net, 31. 8. 2015.

13. Grizold, A., 1999. Obrambni sistem Republike Slovenije. Ljubljana: Ministrstvo za notranje zadeve, Visoka policijsko-varnostna šola. 
14. Guiney, B., 2015. The Mountain Warfare Dilemma. V Marine Corps Gazette, Vol 99, Issue 1. http://www.mca-marines.org, 25. 8. 2015.

15. Hodges, F. B., 2015. Uradni obisk poveljnika kopenskih sil ZDA za Evropo. Ljubljana, Poljče, 23. 4. 2015.

16. Jomini, A. H., 1862. The Art of War. http://www.manybooks.net, 31. 8. 2015.

17. Kuhar, M., 2004. Vojaško gorništvo. Ljubljana: Defensor.

18. Kuhar, M., 2008. Taktika bojevanja v gorah. Ljubljana: Defensor.

19. Kuhar, M., 2014. Usposabljanje za gorsko in zimsko bojevanje. VRevija Obramba, april 2014, str. 23-26. Ljubljana: Defensor.

20. Kupchan, A. C. in Kupchan, A. C., 1995. The Promise of Collective Security. VInternational security, Vol. 20, pp. 52-61. Cambridge: MIT Press.

21. Liddel Hart, B. H., 1967. Strategy. New York: Praeger.

22. NATO Mountain Warfare Centre of Excellence Concept, 2014. Poljče: MW COE.

23. NSA, 2011. NATO Glossary of Standardization Terms and Definitions, AAP-42. Edition B, version 1. Brussels: NATO Standardization Agency.

24. NATO Mountain Warfare Centre of Excellence Memorandum of Understanding, 2014. Poljče: $M W$ COE.

25. NORDREGIO, 2004. Mountain Areas in Europe: Analysis of mountain areas in EU member states, acceding and other European countries. Stockholm: Nordic Centre for Spatial Development. http://www.nordregio.se, 10. 6. 2015.

26. Palomeros, J. P., 2014. Uradni obisk poveljnika zveze Nato za transformacijo. Ljubljana, Poljče, 18. 11. 2014.

27. Pipan, D. E., 2011. Slovenci v avstro-ogrskih vojaških gorskih enotah pred in med prvo svetovno vojno. http://www.zvgs.si/, 10. 6. 2015.

28. Poveljstvo Nata za transformacijo. http://www.nato.act.int, 24. 8. 2015.

29. Stanhope, M., 2005. Proučevanje Natovega preoblikovanja. V Revija NATO, pomlad 2005, Ljubljana. http://www.nato.int/docu/review/, 15. 6. 2015.

30. Stoltenberg, J., 2015. Uradni obisk generalnega sekretarja zveze Nato. Ljubljana, Poljče, 13. 7. 2015.

31. Svetličič, M., 2002. Nacionalni interes - ovira ali spodbuda razvoju. V Teorija in praksa, št. 39/4, str. 523-547. Ljubljana: FDV.

32. Šteiner, A., 2008. Center odličnosti NATO. V Revija Obramba, marec 2008, str. 4-5. Ljubljana: Defensor.

33. Tavčar, M., 2009. Management in organizacija: Sinteza konceptov organizacije kot instrumenta in kot skupnosti interesov. Koper: Fakulteta za management.

34. The NATO Lessons Learned Handbook, 2011. Lisbon: Joint Alliance Lessons Learned Centre. http://www.jallc.nato.int, 30. 7. 2015.

35. Türk, D., 2007. Temelji mednarodnega prava. Ljubljana: GV založba.

36. Vlada RS, 2015. Deklaracija o zunanji politiki Republike Slovenije (predlog). Ljubljana: Državni zbor RS. http://www.dz-rs.si, 24. 6. 2015.

37. Wiecker, V., 2015. Uradni obisk načelnika Generalštaba oboroženih sil Republike Nemčije. Ljubljana, Poljče, 7. 5. 2015.

38. Zupančič, M., 2015. Mountain Warfare in Future NATO Operations. V The Transformer, Summer 2015, p. 7. Norfolk: ACT. 